Atmos. Chem. Phys., 13, 10633-10644, 2013

www.atmos-chem-phys.net/13/10633/2013/

doi:10.5194/acp-13-10633-2013

(c) Author(s) 2013. CC Attribution 3.0 License.

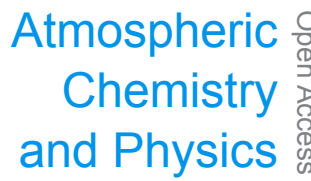

\title{
The variability of methane, nitrous oxide and sulfur hexafluoride in Northeast India
}

\author{
A. L. Ganesan ${ }^{1}$, A. Chatterjee ${ }^{2}$, R. G. Prinn ${ }^{1}$, C. M. Harth ${ }^{3}$, P. K. Salameh ${ }^{3}$, A. J. Manning ${ }^{4}$, B. D. Hall ${ }^{5}$, J. Mühle ${ }^{3}$, \\ L. K. Meredith ${ }^{1}$, R. F. Weiss ${ }^{3}$, S. O'Doherty ${ }^{6}$, and D. Young ${ }^{6}$ \\ ${ }^{1}$ Center for Global Change Science, Massachusetts Institute of Technology, Cambridge, Massachusetts, USA \\ ${ }^{2}$ Environmental Sciences Section, Bose Institute, Kolkata, India \\ ${ }^{3}$ Scripps Institution of Oceanography, University of California San Diego, La Jolla, California, USA \\ ${ }^{4}$ Atmospheric Dispersion Group, Met Office, Exeter, UK \\ ${ }^{5}$ NOAA Earth System Research Laboratory, Boulder, Colorado, USA \\ ${ }^{6}$ Atmospheric Chemistry Research Group, University of Bristol, Bristol, UK
}

Correspondence to: A. L. Ganesan (aganesan@mit.edu)

Received: 16 May 2013 - Published in Atmos. Chem. Phys. Discuss.: 27 June 2013

Revised: 11 September 2013 - Accepted: 17 September 2013 - Published: 4 November 2013

\begin{abstract}
High-frequency atmospheric measurements of methane $\left(\mathrm{CH}_{4}\right)$, nitrous oxide $\left(\mathrm{N}_{2} \mathrm{O}\right)$ and sulfur hexafluoride $\left(\mathrm{SF}_{6}\right)$ from Darjeeling, India are presented from December $2011\left(\mathrm{CH}_{4}\right) /$ March $2012\left(\mathrm{~N}_{2} \mathrm{O}\right.$ and $\left.\mathrm{SF}_{6}\right)$ through February 2013. These measurements were made on a gas chromatograph equipped with a flame ionization detector and electron capture detector, and were calibrated on the Tohoku University, the Scripps Institution of Oceanography (SIO)98 and SIO-2005 scales for $\mathrm{CH}_{4}, \mathrm{~N}_{2} \mathrm{O}$ and $\mathrm{SF}_{6}$, respectively. The observations show large variability and frequent pollution events in $\mathrm{CH}_{4}$ and $\mathrm{N}_{2} \mathrm{O}$ mole fractions, suggesting significant sources in the regions sampled by Darjeeling throughout the year. By contrast, $\mathrm{SF}_{6}$ mole fractions show little variability and only occasional pollution episodes, likely due to weak sources in the region. Simulations using the Numerical Atmospheric dispersion Modelling Environment (NAME) particle dispersion model suggest that many of the enhancements in the three gases result from the transport of pollutants from the densely populated Indo-Gangetic Plains of India to Darjeeling. The meteorology of the region varies considerably throughout the year from Himalayan flows in the winter to the strong south Asian summer monsoon. The model is consistent in simulating a diurnal cycle in $\mathrm{CH}_{4}$ and $\mathrm{N}_{2} \mathrm{O}$ mole fractions that is present during the winter but absent in the summer and suggests that the signals measured at Darjeeling are dominated by large-scale $(\sim 100 \mathrm{~km})$ flows rather than local $(<10 \mathrm{~km})$ flows.
\end{abstract}

\section{Introduction}

Methane $\left(\mathrm{CH}_{4}\right)$, nitrous oxide $\left(\mathrm{N}_{2} \mathrm{O}\right)$, and sulfur hexafluoride $\left(\mathrm{SF}_{6}\right)$ are potent greenhouse gases that play a significant role in the climate system. Atmospheric $\mathrm{CH}_{4}$ is the second largest contributor to anthropogenic radiative forcing after carbon dioxide $\left(\mathrm{CO}_{2}\right)$ at $0.48 \mathrm{Wm}^{-2}$ (Forster et al., 2007). The major sink for $\mathrm{CH}_{4}$ is reaction with the hydroxyl radical $(\mathrm{OH})$, resulting in an atmospheric budget lifetime of $7.8 \mathrm{yr}$ (Prather and Hsu, 2010). Globally, a large amount $\mathrm{CH}_{4}$ emissions are naturally occurring, and primarily originate from wetlands; but anthropogenic sources, which include rice paddies, ruminants, biomass burning, and fossil fuel emissions make up $\sim 60 \%$ of the $\mathrm{CH}_{4}$ budget (Chen and Prinn, 2006; Denman et al., 2007). In India, over $75 \%$ of $\mathrm{CH}_{4}$ emissions are from the agricultural sector, and are created by enteric fermentation and microbial processes in rice paddies (Indian Network for Climate Change Assessment, 2007). The peak in $\mathrm{CH}_{4}$ emissions occurs during the wet season (June to September), when the majority of rice in south Asia is grown (Pathak et al., 2005).

Nitrous oxide is a powerful greenhouse gas and ozonedepleting substance. Based on current mole fractions, $\mathrm{N}_{2} \mathrm{O}$ has the third-largest anthropogenic radiative forcing (Hofmann et al., 2006; Montzka et al., 2011). The main sink for $\mathrm{N}_{2} \mathrm{O}$ occurs in the stratosphere where photolysis and reaction with $\mathrm{O}\left({ }^{1} \mathrm{D}\right)$ result in an atmospheric budget lifetime 
of $118 \mathrm{yr}$ (Prather and Hsu, 2010). Nitrous oxide also plays a significant role in the chemistry of the ozone layer and is the primary source of stratospheric $\mathrm{NO}_{\mathrm{x}}$. Though its ozonedepletion potential (ODP) is low (0.017), its large atmospheric burden and long lifetime make $\mathrm{N}_{2} \mathrm{O}$ the largest ODPweighted emitter (Ravishankara et al., 2009). The principal global sources of $\mathrm{N}_{2} \mathrm{O}$ occur naturally from microbial processes in soils and in the ocean, and these sources account for approximately $60 \%$ of the budget. The remainder of emissions is anthropogenically emitted through the usage of fertilizers in agricultural soils, from biomass burning, sewage, vehicle emissions, and other, smaller sources (Denman et al., 2007). The dominant $\mathrm{N}_{2} \mathrm{O}$ source in India is fertilized soils used in rice and wheat agriculture; this comprises over $60 \%$ of national emissions (Indian Network for Climate Change Assessment, 2007).

With a $100 \mathrm{yr}$ global warming potential of 22800 , sulfur hexafluoride is the most potent greenhouse gas regulated under the Kyoto Protocol (Forster et al., 2007; Rinsland et al., 1990). Its lifetime of $3200 \mathrm{yr}$ owes to the fact that destruction of $\mathrm{SF}_{6}$ only occurs in the mesosphere, making it essentially inert on human timescales (Ravishankara et al., 1993). Measurements of $\mathrm{SF}_{6}$ from firn air have shown only a small pre-industrial concentration of $6 \times 10^{-3} \mathrm{pmol} \mathrm{mol}^{-1}$, suggesting that $\mathrm{SF}_{6}$ is almost entirely anthropogenically emitted (Vollmer and Weiss, 2002). Emissions globally and in India are largely from the electrical industry, and occur through leakage from high-voltage switchgear and during the maintenance and refill process (Niemeyer and Chu, 1992).

Global monitoring of atmospheric mole fractions has existed for several decades for $\mathrm{CH}_{4}$ and $\mathrm{N}_{2} \mathrm{O}$, and has been implemented in the past decade for $\mathrm{SF}_{6}$ (Prinn et al., 2000; Dlugokencky et al., 2005; Hall et al., 2007). Global emissions of the three gases have been deduced in previous studies using data from global measurement networks. Methane emissions have been estimated to be between $500-600 \mathrm{Tg} \mathrm{CH}_{4} \mathrm{yr}^{-1}$ from 1996-2004 (Chen and Prinn, 2006; Bergamaschi et al., 2009). A recent increase in the growth rate of $\mathrm{CH}_{4}$ was detected in 2007 following a decade of stability; the cause of this increase remains unresolved but is speculated to be changes in tropical emissions (Rigby et al., 2008; Dlugokencky et al., 2009; Bousquet et al., 2011). Global $\mathrm{N}_{2} \mathrm{O}$ emissions were estimated to be between $17.2-20.1 \mathrm{TgN} \mathrm{yr}^{-1}$ from 2005-2009 and global $\mathrm{SF}_{6}$ emissions were found to be 7.2$7.4 \mathrm{Gg} \mathrm{yr}^{-1}$ in 2008 (Saikawa et al., 2013; Thompson et al., 2013; Park et al., 2012; Rigby et al., 2010; Levin et al., 2010).

Quantification of regional emissions using atmospheric measurements is less constrained than the global burden primarily because it requires measurements that sample air masses containing regional pollution rather than measurements that sample the "background". Previous measurements in south Asia include low-frequency flask measurements and satellite observations. Between 1993-2002 and from 2009-present, flasks have been collected biweekly at a station in Cabo de Rama (Cape Rama), India and mea- sured for $\mathrm{CH}_{4}$ and $\mathrm{N}_{2} \mathrm{O}$ mole fraction at the Commonwealth Scientific and Industrial Research Organization (CSIRO) (Bhattacharya et al., 2009). Previous and ongoing satellite measurements include measurements by SCanning Imaging Absorption spectroMeter for Atmospheric CHartographY (SCIAMACHY), Atmospheric Infrared Sounder (AIRS), and Greenhouse gases Observing SATellite (GOSAT) (Bergamaschi et al., 2009; Xiong et al., 2009; Parker et al., 2011). In Xiong et al. (2009), satellite retrievals of $\mathrm{CH}_{4}$ showed a plume-like enhancement of $\mathrm{CH}_{4}$ over south Asia during the monsoon, suggesting enhanced emissions and deep convection during this period. Samples collected by Civil Aircraft for the Regular Investigation of the atmosphere Based on an Instrument Container (CARIBIC) flights have also shown a similar monsoon plume (Schuck et al., 2010).

Of the many global emission estimates of these gases, only a few studies have utilized atmospheric measurements from south Asia. In Bergamaschi et al. (2009), $\mathrm{CH}_{4}$ emissions over Asia (including India, China, and southeast Asia) were estimated using SCIAMACHY retrievals with a $\mathrm{CO}_{2}$ proxy and NOAA surface data at $128.4 \mathrm{Tg} \mathrm{yr}^{-1}$. The study showed the large spatial and temporal variability in $\mathrm{CH}_{4}$ source strength within India. However, satellite retrievals over India are often compromised in areas with frequent cloud cover and high aerosol optical depth (Parker et al., 2011). Retrievals based on $\mathrm{CO}_{2}$ proxies may have additional uncertainties in India's case, due to the sparsity of available $\mathrm{CO}_{2}$ measurements in the region. The importance of including Cape Rama measurements in regional emission estimates has been demonstrated in Huang et al. (2008). An inversion for $\mathrm{N}_{2} \mathrm{O}$ emissions performed with Cape Rama data showed significant error reduction compared to one in which Indian measurements were not included; the results also showed significant error reduction compared to when Indian measurements were not included; they also showed that large spatial covariances exist between emissions derived for south Asia and other regions without the use of these measurements. This study found the $\mathrm{N}_{2} \mathrm{O}$ emissions of south Asia (region encompassing India, the Middle East, and portions of China) to be $0.95 \mathrm{TgN} \mathrm{yr}^{-1}$ from 2002-2005. In another study, aggregated south Asian and southeast Asian $\mathrm{N}_{2} \mathrm{O}$ emissions were deduced using global network and Cape Rama data to be $3.63 \mathrm{TgN} \mathrm{yr}^{-1}$ in 2008 (Saikawa et al., 2013). Total 2008 $\mathrm{SF}_{6}$ emissions for all non-UNFCCC (United Nations Framework Convention on Climate Change) Asian countries have been estimated to be $4.1 \mathrm{Gg} \mathrm{yr}^{-1}$ (Rigby et al., 2010).

Due to the importance of using measurements from south Asia in estimating emissions from the region, measurements of $\mathrm{CH}_{4}, \mathrm{~N}_{2} \mathrm{O}$ and $\mathrm{SF}_{6}$ have been collected from Darjeeling, India from December $2011\left(\mathrm{CH}_{4}\right) /$ March 2012 $\left(\mathrm{N}_{2} \mathrm{O}\right.$ and $\left.\mathrm{SF}_{6}\right)$ through February 2013 and are currently ongoing. These measurements comprise a pilot study for the Darjeeling station, which is the first to measure these three gases in situ in India and with instrumentation sampling at high-frequency, resulting in measurements that could 
provide important constraints for top-down emissions estimation.

\section{Experimental methods}

A fully automated, custom-built sampling system was developed and equipped with a gas chromatograph (GC, Agilent Technologies, Santa Clara, CA, model 6890N) with a flame ionization detector (FID) and micro electron capture detector $(\mu \mathrm{ECD}$, henceforth referred to as $\mathrm{ECD})$ to measure $\mathrm{CH}_{4}$ (FID), $\mathrm{N}_{2} \mathrm{O}$, and $\mathrm{SF}_{6}$ (ECD). The instrument was based on similar designs by Prinn et al. (2000), Hall et al. (2007, 2011), and Dlugokencky et al. (2005). Full details of the instrument design are provided in the supplementary material. Analysis time for each sample has varied between ten and twelve minutes in this study.

Though measurements with the FID and ECD are performed simultaneously, each channel is discussed separately. The carrier gas for the FID is nitrogen at a purity of $99.999 \%$. Hydrogen fuel gas at $99.999 \%$ purity is supplied to the FID at $60 \mathrm{~mL} \mathrm{~min}^{-1}$ along with zero air from a pure air generator equipped with a $\mathrm{CH}_{4}$ reactor (Aadco Instruments Inc, Cleves, OH, model 737-1A) at $275 \mathrm{~mL} \mathrm{~min}^{-1}$. After the FID sample loop has equilibrated to ambient pressure, the sample is injected through a 10-port 2-position backflush valve (BFV) onto a HayeSep Q 100/120 pre-column (3 ft (0.91 m), $1 / 8 \mathrm{in}(0.318 \mathrm{~cm}) \mathrm{OD})$, and main-column $(6 \mathrm{ft}(1.83 \mathrm{~m}), 1 / 8$ in $(0.318 \mathrm{~cm}) \mathrm{OD})$. After $\mathrm{CH}_{4}$ has been eluted off the precolumn, the BFV is switched to the backflush position, at which time the pre-column is backflushed and $\mathrm{CH}_{4}$ continues through the main-column to the FID. The column and backflush flow rates are $40 \mathrm{~mL} \mathrm{~min}^{-1}$ and $20 \mathrm{~mL} \mathrm{~min}^{-1}$, respectively. The column temperature is held isothermally at $85^{\circ} \mathrm{C}$ and the detector is maintained at $190^{\circ} \mathrm{C}$.

For the ECD channel, carrier gas is a $10 \% \mathrm{CH}_{4}$ in argon mixture (P-10) at a purity of $99.995 \%$ (relative to the mixture). After equilibration to ambient pressure, the sample is injected through a 10-port 2-position BFV onto a Porapak $\mathrm{Q} 80 / 100$ pre-column (1 $\mathrm{ft}(0.3 \mathrm{~m}), 3 / 16$ in $(0.476 \mathrm{~cm})$ OD) and main-column $(2 \mathrm{ft}(0.61 \mathrm{~m}), 3 / 16$ in $(0.476 \mathrm{~cm}) \mathrm{OD})$, where $\mathrm{N}_{2} \mathrm{O}$ and $\mathrm{SF}_{6}$ are separated from air. After oxygen is eluted from these columns, it is "heart-cut" out to the vent, upon which the BFV is switched so that the pre-column is backflushed while $\mathrm{N}_{2} \mathrm{O}$ and $\mathrm{SF}_{6}$ continue through the maincolumn onto a third Molecular Sieve $5 \AA 40 / 60$ post-column ( $3 \mathrm{ft}(0.91 \mathrm{~m}), 1 / 8$ in $(0.318 \mathrm{~cm}) \mathrm{OD})$. On the post-column, the order of elution of $\mathrm{N}_{2} \mathrm{O}$ and $\mathrm{SF}_{6}$ is reversed so that $\mathrm{SF}_{6}$ is detected before the much larger $\mathrm{N}_{2} \mathrm{O}$ peak. This results in an increase in $\mathrm{SF}_{6}$ peak height and improved precision. Nitrous oxide is co-eluted with $\mathrm{CO}_{2}$ on this post-column, but care is taken to ensure that the $\mathrm{N}_{2} \mathrm{O}$ response is not affected by variations in ambient $\mathrm{CO}_{2}$. This third post-column is contained in a custom-built oven that is controlled and modulated by one of the heated zones on the GC. The pre- and main- columns are maintained at $85^{\circ} \mathrm{C}$ for consistency with the FID system, the post-column is held at $180^{\circ} \mathrm{C}$ and the ECD detector temperature is maintained at $340^{\circ} \mathrm{C}$. Column flow is $35 \mathrm{~mL} \mathrm{~min}^{-1}$ during the heart-cut, increases to $40 \mathrm{~mL} \mathrm{~min}^{-1}$ through the post-column, and is $30 \mathrm{~mL} \mathrm{~min}^{-1}$ during backflush. P-10 exhaust is vented outside the lab to prevent any accidental contamination of the FID system with $\mathrm{CH}_{4}$.

Measurements were calibrated using a dry, compressed air standard in an aluminum cylinder (Scott Marrin, Riverside, CA) at the Scripps Institution of Oceanography (SIO) in July 2011. The cylinder was first passivated with air for approximately a week and then evacuated and re-filled. The standard was calibrated to values of $1835.01 \pm 1.16 \mathrm{nmol} \mathrm{mol}^{-1}, 324.60 \pm 0.09 \mathrm{nmol} \mathrm{mol}^{-1}$, and $7.55 \pm 0.04 \mathrm{pmol} \mathrm{mol}^{-1}$ for $\mathrm{CH}_{4}, \mathrm{~N}_{2} \mathrm{O}$ and $\mathrm{SF}_{6}$, respectively, using the Advanced Global Atmospheric Gases Experiment (AGAGE) multi-detector system (for $\mathrm{CH}_{4}$ and $\mathrm{N}_{2} \mathrm{O}$ ) and the AGAGE "Medusa" GC-MS system (for $\mathrm{SF}_{6}$ ). $\mathrm{CH}_{4}, \mathrm{~N}_{2} \mathrm{O}$ and $\mathrm{SF}_{6}$ were calibrated on the Tohoku University, SIO-98 and SIO-2005 scales, respectively (Prinn et al., 2000; Miller et al., 2008). Standard and air samples were measured alternately.

Due to the high fill pressure and large volume of the cylinder, enough standard gas is available in the cylinder to calibrate the instrument for three years. Studies using dry standards in aluminum cylinders have been used widely and have shown no significant drift for each of the three gases over the time frame of this study (Dlugokencky et al., 2005; Hall et al., 2007, 2011). To determine any possible drift in the standard, the ratios of the standard and two other cylinders that were calibrated at SIO have been monitored. No drift within the repeatability of the instrument has been observed for the three gases, and the measured values match the SIOcalibrated values in the cylinders, likely indicating that the two measurement systems are also measuring the same values.

On this system, median $1 \sigma$ repeatability achieved for the three gases over the period of study was $1.2 \mathrm{nmol} \mathrm{mol}^{-1}$ $\left(\mathrm{CH}_{4}\right), 0.17 \mathrm{nmol} \mathrm{mol}^{-1}\left(\mathrm{~N}_{2} \mathrm{O}\right)$ and $0.03 \mathrm{pmol} \mathrm{mol}^{-1}\left(\mathrm{SF}_{6}\right)$, which lie within the ranges typically achieved for these gases at AGAGE stations (Prinn et al., 2000; Cunnold et al., 2002; Huang et al., 2008; Rigby et al., 2010).

At the station, meteorological measurements of air temperature, barometric pressure, wind speed and direction, solar radiation, and precipitation were collected using sensors that were installed prior to this study in 2010 . The components of the meteorological station are found in the supplementary material. The measurements used in this study are one minute averages of $10 \mathrm{~Hz}$ data.

\section{Field site}

The field site selected for this study is a high-altitude hill station in the eastern Himalayas $\left(27^{\circ} 02^{\prime} \mathrm{N}, 88^{\circ} 15^{\prime} \mathrm{E}\right.$, 
2194 ma.s.l., Chatterjee et al., 2010) in Darjeeling, India. Instrumentation is housed at the National Facility of Astroparticle Physics and Space Science of the Bose Institute. Darjeeling has population of approximately 100000 and has developed on the northwest-facing slope of a northeast-southwest oriented ridge (Fig. 1). The main town center in Darjeeling is located at approximately 2000 ma.s.l., $200 \mathrm{~m}$ below the station and $250 \mathrm{~m}$ below the ridgetop. It is located $\sim 50 \mathrm{~km}$ north of the densely populated Indo-Gangetic Plains. The measurement station is located in a relatively unpopulated area of Darjeeling. Only one road leads to the Bose Institute, shortly after which it ends; consequentially, there is very little traffic on this road.

The mountain slope below Darjeeling contains several tea plantations, where synthetic nitrogen fertilizers are used seasonally; these fertilizers could be a local source of $\mathrm{N}_{2} \mathrm{O}$. Wood biomass burning is prevalent throughout the mountain region and occurs mainly during the winter season; this may contribute local sources of $\mathrm{CH}_{4}$ and $\mathrm{N}_{2} \mathrm{O}$. Additionally, there may be small natural gas sources from fuel, another potential local influence on $\mathrm{CH}_{4}$. Vehicular emissions also exist, mainly from tourist vehicles which operate predominantly on diesel fuel, though their contribution to $\mathrm{CH}_{4}$ and $\mathrm{N}_{2} \mathrm{O}$ is thought to be small. Local sources of $\mathrm{SF}_{6}$ are expected to be low. The nearest high-voltage power substation is located in Ghoom, approximately $10 \mathrm{~km}$ away from Darjeeling, but it could be a potential source of $\mathrm{SF}_{6}$.

The inlet line to the instrument was installed approximately halfway up a ten meter tower that was built on the roof of a four-story building. Meteorological sensors were mounted above the instrument inlet at the top of the tower. Details of the inlet setup are provided in the supplementary material.

\section{Transport model}

A transport model was used to diagnose important signals in the trace gas data and to characterize the meteorology of the site. The UK Met Office's Numerical Atmospheric dispersion Modelling Environment (NAME) III is a Lagrangian particle dispersion model used to simulate atmospheric transport (Ryall and Maryon, 1998; Jones et al., 2007) and has been used extensively for similar applications and at various sites (Manning et al., 2011, 2003; O'Doherty et al., 2004; Reimann et al., 2005). NAME calculates transport by following a large number of particles "backwards" in time from their release at the measurement site. The particles are advected by three-dimensional meteorological fields supplied by a Numerical Weather Prediction (NWP) model. Additional turbulent and low-frequency meandering motions are simulated by a random-walk formulation (Morrison and Webster, 2005). Chemistry, wet and dry deposition, and radioactive decay can be included, but, owing to the long lifetimes of the gases being studied here and the length of the

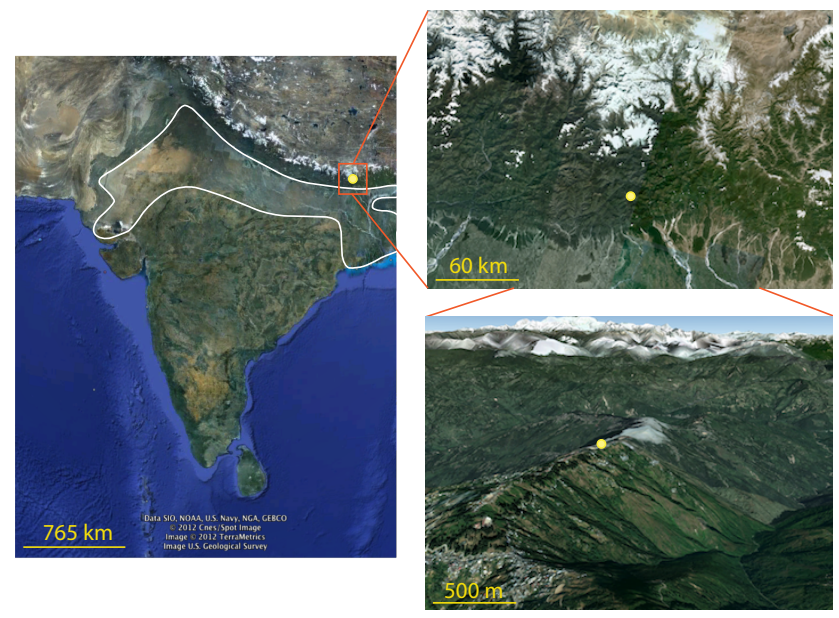

Fig. 1. Location of field site in Darjeeling, India $\left(27^{\circ} 02^{\prime} \mathrm{N}\right.$, $88^{\circ} 15^{\prime}$ E, 2194 ma.g.1., yellow dot) in the Himalayan foothills of Northeast India. The white border shows the approximate location of the Indo-Gangetic Plains of India. Images are from Google Earth.

back trajectories, particles were assumed to be inert. The computational domain used for the model runs over Darjeeling was from $5-50^{\circ} \mathrm{N}$, and $50-120^{\circ} \mathrm{E}$, covering India, China, southeast Asia, and part of the Middle East, and covering up to $19 \mathrm{~km}$ vertically. Particles were released from the Darjeeling station $\left(27^{\circ} 02^{\prime} \mathrm{N}, 88^{\circ} 15^{\prime} \mathrm{E}\right)$ at a release height between $450-550 \mathrm{ma}$ a.g.l. and were released randomly throughout this $100 \mathrm{~m}$ column. The particle release height was chosen as a compromise between the true station height (2194 m.a.s.1.) and the height of the station in the model (1340 ma.s.1.). A release height between the true and model station heights is typically chosen at mountain sites (Brunner et al., 2012; Tuzson et al., 2011). Particles were released continuously at a rate of 20000 particles $\mathrm{h}^{-1}$ at a mass of $1 \mathrm{~g} \mathrm{~s}^{-1}$ for each three hour period and tracked backwards for 30 days.

NWP meteorological fields from the Met Office's Unified Model (UM) were used to drive NAME. Model simulations utilized the UM South Asian Model (SAM), which is available from 2010 onwards for the south Asian domain at $0.11^{\circ}$ horizontal resolution, for 70 vertical levels, and at $3 \mathrm{~h}$ temporal resolution. Seven days after release, at which time particles are assumed to have left the Himalayas, or if and when particles have left the SAM domain prior to this time, the UM's global meteorology at $0.352^{\circ} \times 0.234^{\circ}$ (long. $\times$ lat.) resolution was used. The model time step in all simulations was $5 \mathrm{~min}$.

NAME outputs "air histories" or the influence of surface emissions on the measured concentrations at the station and directly provides the sensitivity of a measurement in Darjeeling to emissions from the domain. Air histories were created at $0.352^{\circ} \times 0.234^{\circ}$ resolution for a $0-100 \mathrm{~m}$ a.g.l. vertical level every three hours. 


\section{Results}

Measurements of $\mathrm{CH}_{4}, \mathrm{~N}_{2} \mathrm{O}$ and $\mathrm{SF}_{6}$ mole fractions from Darjeeling, India are presented for the period from December 2011 for $\mathrm{CH}_{4}$ and March 2012 for $\mathrm{N}_{2} \mathrm{O}$ and $\mathrm{SF}_{6}$ through February 2013. Meteorological measurements and air histories from the period are used to explain the signals observed in the mole fraction measurements.

\subsection{Air histories and meteorology}

Monthly median air history maps are shown for each season and indicate the regions sampled by Darjeeling (Fig. 2). January air histories show surface influence from both east and west of the station, indicating that air from both sides of the site is sampled after particles are released from Darjeeling. This likely results from diurnal changes in wind direction caused by thermally-driven slope winds in the mountains. During the day, air flows from the plains to the mountains and is locally upslope, while at night, air usually descends from the mountains down to the plains and is locally downslope. During the winter, the greatest sensitivity to the surface is localized to the Himalayan region. In April, the east and west "lobes" caused by diurnal winds are still seen but southerly winds are additionally present. In these 30-day integrated maps, this suggests that a fraction of particles move with the diurnal winds and a fraction are carried by the largerscale flow. In the summer period, only the dominant summer monsoon flow is observed. During the monsoon, the large temperature contrast between the Asian landmass and Indian Ocean results in a surface low pressure system over India (Hoskins and Rodwell, 1995). A strong southwesterly flow (known as the southwest monsoon) brings moisture-laden air from the ocean to the continent and results in intense precipitation over south Asia. This summer monsoon is also characterized by strong convection over the heating landmass that can transport pollutants to the upper troposphere (Schuck et al., 2010; Xiong et al., 2009). In October, following the summer monsoon, the "lobes" return and air histories are similar to those seen in January. The seasonal differences in the air histories show the different flows captured between winter and summer and suggests that Darjeeling samples air masses from several regions of south Asia throughout the year.

To assess the ability of the UM to reproduce flows at the site as well as to understand the origin of air masses sampled at the site, observed and modeled wind speeds and wind directions are compared using wind roses (Fig. 3). UM modeled winds are shown at 500 ma.g.1., which is the mid-point particle release height used in the model.

Horizontal wind speeds at Darjeeling reach a maximum in April (not shown) during the pre-monsoon period, and a minimum in July when vertical motion is strong in the Himalayas. Wind speeds are almost always larger in the 500 ma.g.l. model winds than in the 15 ma.g.l. observed (a)

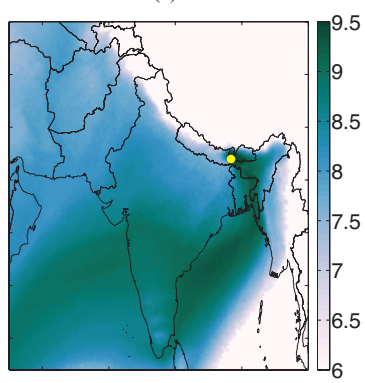

(c)

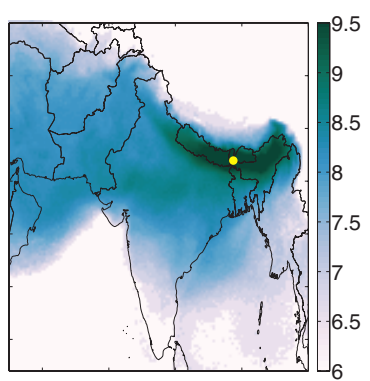

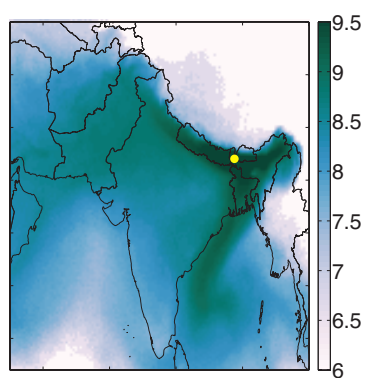

(b)

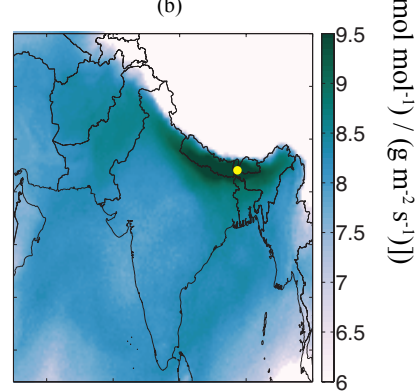

Fig. 2. Monthly median air histories for (a) January 2012 (b) April 2012 (c) July 2012 (d) October 2012. Color bar is a logarithmic scale showing the sensitivity of Darjeeling (yellow dot) mole fractions in pmol mol$l^{-1}$ to emissions of any inert gas in $\mathrm{g} \mathrm{m}^{-2} \mathrm{~s}^{-1}$.

winds because surface friction is less significant at this height in the model.

In January, 500 ma.g.l. modeled and observed winds at 15 ma.g.l. show good agreement in wind direction. Air flow is southerly during the day and northeasterly at night, which is consistent with the direction of plains-to-mountain winds. Upslope and downslope winds local to the Darjeeling ridge (which is oriented towards the northeast) would result in observed and modeled diurnal winds that are oriented to the southeast and northwest, respectively, if the flow being captured was a local process. This diurnal shift in wind direction, which is well-captured by the model, is responsible for the "lobes" seen in the winter air history maps (Fig. 2). In July, the diurnal cycle in wind direction is not significant, and this lack of diurnal cycle is reproduced in the model as well. Both the model and observations show a consistent southeasterly wind direction at this time, resulting from air masses that originate in the southwest but first pass over the Bay of Bengal before reaching Darjeeling from the southeast. The consistency of the model with observations suggests that the air sampled at Darjeeling is representative of the "large-scale" flows of the region rather than the local mesoscale flows.

This comparison has been performed for a variety of model heights. Only small differences exist in the meteorology at heights between $400-600$ ma.g.l., but surface meteorology shows a better fit to wind speed and a worse fit for wind direction. This tradeoff between wind speed and wind 
(a)
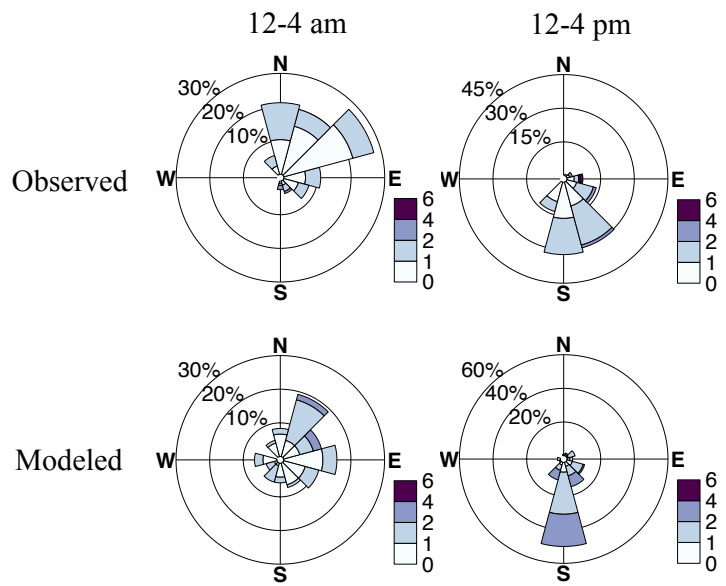

(b)
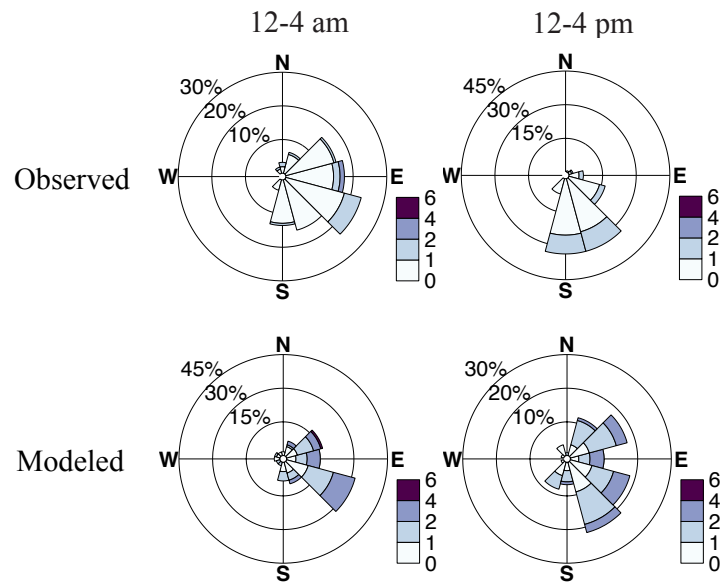

Fig. 3. Wind roses showing percentage of time with given wind direction and speed (color bar, $\mathrm{m} \mathrm{s}^{-1}$ ). Observed (15 m a.g.1.) and modeled (500 m a.g.1.) wind roses for 00:00-04:00 and 12:00-16:00 for (a) January 2012 and (b) July 2012.

direction at the release height could contribute to errors in the derived air histories.

Sensible heat flux is a measure of the heat transferred between the surface and atmosphere, and is a major driver in the formation of slope winds. Sensible heat flux from the UM was averaged into diurnal values for January 2012 and July 2012, which were used to diagnose seasonal variability in the diurnal cycle (Supplement). While sensible heat flux in both months reaches a maximum at $\sim 12: 00$, it was found that the wintertime diurnal sensible heat flux was considerably larger than that of the summer. This could occur for several reasons: (1) winter days in Darjeeling are very clear and are generally cloud-free, resulting in more solar radiation reaching the surface; (2) the winter is dry while the summer is humid, and humidity results in solar radiation being absorbed by the surface to be converted to latent heat flux rather than to sensible heat flux; (3) there is a dominant synoptic flow in the summer, which may be stronger than the diurnal flows.

\subsection{Trace gas measurements}

Darjeeling intercepts air with surrounding "regional" pollution, air that characterizes the "background" and occasionally air with "local" influence. These three types of signals are defined broadly as the signal characterizing emissions from south Asia, the signal pertaining to well-mixed air masses and the signal characterizing local Darjeeling emissions. The measurement time series from December 2011 through February 2013 for the three gases at Darjeeling are compared with "pollution-removed" monthly mean mole fractions from several AGAGE stations (Fig. 4).

Sulfur hexafluoride is discussed first, as its mole fractions at Darjeeling generally vary slowly with time and pollution episodes are infrequent. Though Darjeeling lies approximately halfway between Ireland and Barbados latitudinally, its signal is most similar in magnitude to that of Ragged Point, Barbados. This could result from the Himalayas serving as a barrier to the transport of high-latitude air to Darjeeling as well as from the fact that Darjeeling is at a higher altitude than Mace Head, Ireland. The magnitude of pollution events measured at Darjeeling is smaller than those seen at stations that measure high levels of pollution such as Gosan, South Korea, suggesting that sources of $\mathrm{SF}_{6}$ near Darjeeling are weaker or farther away than those sampled at Gosan (Rigby et al., 2010). It is assumed that the $\mathrm{SF}_{6}$ record is indicative of Darjeeling's place within the global latitudinal gradient if few regional sources are present. By contrast, $\mathrm{CH}_{4}$ and $\mathrm{N}_{2} \mathrm{O}$ mole fractions are significantly elevated over the assumed background level, and are elevated even further over Mace Head levels. This suggests that there are strong regional sources present that almost always enhance $\mathrm{CH}_{4}$ and $\mathrm{N}_{2} \mathrm{O}$ over the background, though at occasional times during the winter, their mole fractions exhibit excursions down to the levels of Ragged Point, Barbados. These low excursions could imply either that background air is sampled occasionally or that cleaner mid- to upper tropospheric air is being sampled during times of subsidence.

The monthly mean $\mathrm{CH}_{4}$ mole fraction and $1 \sigma$ variability in January 2012 and July 2012 are 1929.2 (55.7), and 1923.6 (64.8) $\mathrm{nmol} \mathrm{mol}^{-1}$, respectively, values which are similar for both seasons. While it is expected that $\mathrm{CH}_{4}$ and $\mathrm{N}_{2} \mathrm{O}$ emissions peak in summer when wet season production of the two gases is greatest, the influence of the background mole fractions serves to compensate for the effect of increased emissions. In winter, air histories show transport of northern hemispheric (NH) air into India. In summer, the southwest monsoon results in the transport of southern hemispheric (SH) air into India with lower background content of $\mathrm{CH}_{4}$, $\mathrm{N}_{2} \mathrm{O}$, and $\mathrm{SF}_{6}$. To investigate the role of the monsoon, a linear fit was applied to the $\mathrm{SF}_{6}$ data (excluding monsoon months of June to September) and interpolated to mid-July. This represents the value, to first-order, that would be expected given only NH air. The observed July data was averaged into weekly values and compared to the $\mathrm{NH}$-air value. 

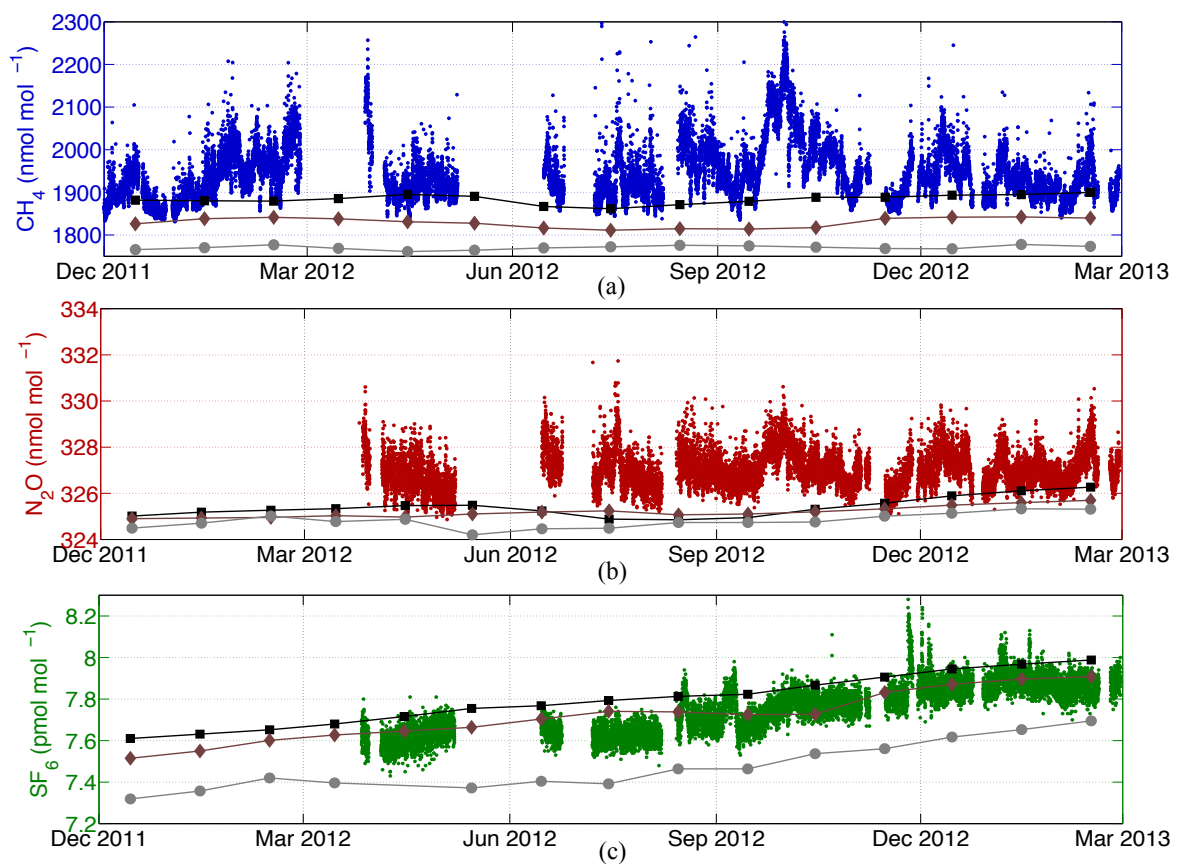

Fig. 4. Measurements of (a) $\mathrm{CH}_{4}$ (blue) (b) $\mathrm{N}_{2} \mathrm{O}$ (red) and (c) $\mathrm{SF}_{6}$ (green) mole fractions from Darjeeling, India. "Pollution-removed" monthly mean mole fractions from AGAGE measurements at Mace Head, Ireland (black squares), Ragged Point, Barbados (brown diamonds) and Cape Matatula, American Samoa (grey circles) are shown for comparison.

A difference of $0.13 \mathrm{pmol} \mathrm{mol}^{-1}$ was found at the peak of the monsoon. Previous studies have shown a seasonal $\mathrm{SF}_{6}$ amplitude of $0.17 \mathrm{pmol} \mathrm{mol}^{-1}$ at the Seychelles (Gloor et al., 2007). It was expected that the difference at Darjeeling, which is a continental site, would be smaller than that observed at the Seychelles because SH air entering India first passes over eastern Africa and the Indian subcontinent before reaching Darjeeling.

A fast Fourier transform (FFT) was applied to each month of $\mathrm{CH}_{4}$ data (for months when continuous data was available for the majority of the month) to diagnose the dominant timescales of variability in each month (Fig. 5). A mean and linear trend were first removed and data were padded with zeros to reach an integral power of 2 data points following Thoning et al. (1989). Because of data gaps in the full data set, the FFT was not applied to the entire time series. Excluding trends in the monthly data, the dominant timescale of variability in the January measurements is diurnal, while in July, the diurnal signal is small. In July, the dominant variability is from synoptic-scale events on timescales of the order of a week. High-frequency (i.e., shorter than $1 \mathrm{~d}$ ) variability is greater in July than in January, suggesting variability in the air masses sampled during the highly convective monsoon period, and variability in source strength as emissions from rice paddies could be episodic or due to greater local influence from nearby Darjeeling sources. A similar spectrum is seen in $\mathrm{N}_{2} \mathrm{O}$ measurements, while $\mathrm{SF}_{6}$ shows greater high-frequency variability in all seasons owing to its lower

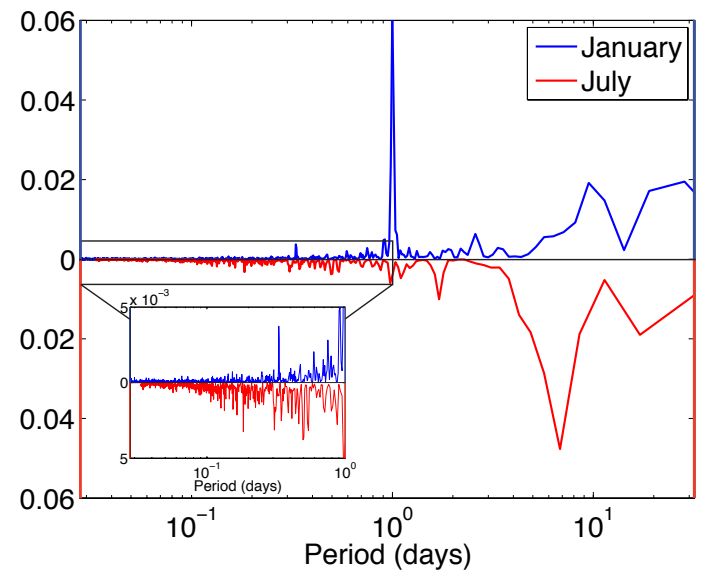

Fig. 5. Power spectrum of January 2012 (blue) and July 2012 (red) $\mathrm{CH}_{4}$ mole fractions normalized by the total of each month. July is shown as a mirror for visualization.

measurement repeatability and lack of a diurnal cycle in any season (supplementary material).

\subsubsection{Pollution events}

Methane and $\mathrm{N}_{2} \mathrm{O}$ generally exhibit concurrent enhancements in their mole fractions. As the $\mathrm{CH}_{4}$ and $\mathrm{N}_{2} \mathrm{O}$ measurement systems only share common sampling, it is unlikely that measurement artifacts would lead to these enhancements, 

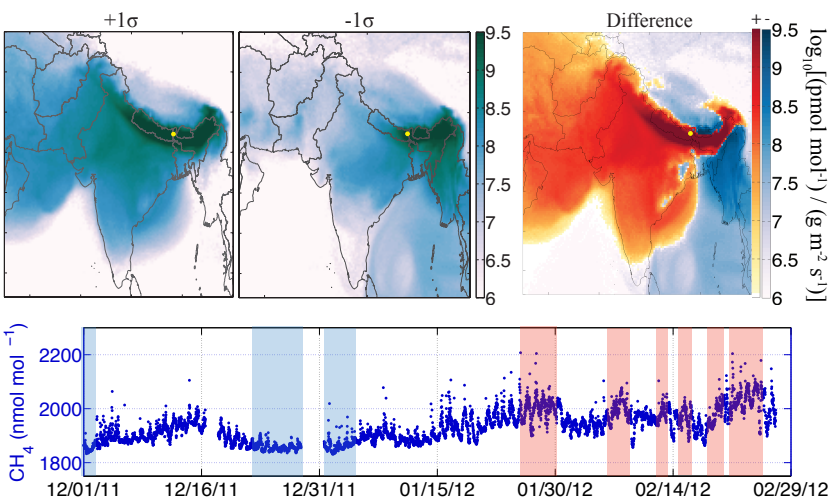

Fig. 6. (Top) Average air histories from Darjeeling (yellow dot) corresponding to $\mathrm{CH}_{4}$ measurements from December 2011 through February 2012 that are $1 \sigma$ above the mean of the period after smoothing (top, left), measurements that are $1 \sigma$ below the mean after smoothing (top, middle) and the difference between the two (top, right). The difference map is shown using two color maps representing the log value of positive and negative differences, respectively. (Bottom) Mole fractions (unsmoothed) from the period are shown with highlighted portions corresponding to the $+1 \sigma$ (red) and $-1 \sigma$ (blue) measurements after smoothing.

suggesting that emission sources for the two gases in the regions sampled by Darjeeling are generally co-located. Though enhancements are concurrent, over the course of the study the ratio of the two gases does not remain constant. Correlation coefficients, $r$, between $\mathrm{CH}_{4}$ and $\mathrm{N}_{2} \mathrm{O}$ and between $\mathrm{CH}_{4}$ and $\mathrm{SF}_{6}$ were computed for winter and summer periods and are provided in the supplementary material.

Methane and $\mathrm{N}_{2} \mathrm{O}$ show greater correlation during the winter than during the summer; the correlation coefficient is 0.90 for the period from December 2012 through February 2013 and 0.63 from June through August 2012 (both significant on a $95 \%$ confidence level according to a $t$ test). Because the timing of events are concurrent (in the winter, the enhancements are largely diurnal), this suggests that the temporal distribution of emissions of the two gases are similar during the winter. In the summer, the simultaneous enhancements in mole fractions but lower correlation coefficient suggests a different temporal distribution of emissions during the period. Emissions of $\mathrm{CH}_{4}$ and $\mathrm{N}_{2} \mathrm{O}$ from rice paddies and fertilized soils, respectively, have been found not to occur simultaneously during the summer monsoon period, as fertilizer application occurs at specific times over the growing season (Pathak et al., 2005; Schuck et al., 2010). The lower correlation could also result from a different distribution of local emissions of the two gases, which is more prominent in the summer when the high-frequency component of variability is more significant.

Enhancements between $\mathrm{CH}_{4}$ (or $\mathrm{N}_{2} \mathrm{O}$ ) and $\mathrm{SF}_{6}$ are not always simultaneous, which reflects a different source distribution for the two gases, assuming that $\mathrm{SF}_{6}$ emissions are constant. The correlation coefficient between $\mathrm{CH}_{4}$ and $\mathrm{SF}_{6}$
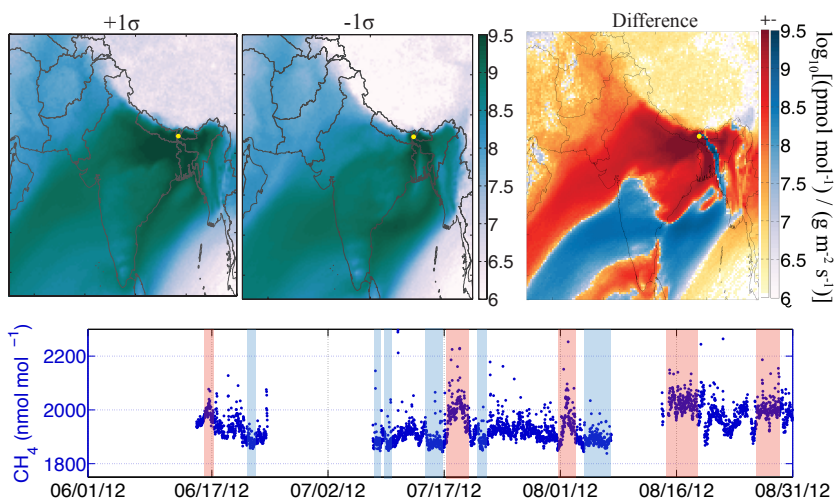

Fig. 7. Same as Fig. 6 but for June 2012 through August 2012.

is 0.22 for the period from December 2012 through February 2013, and 0.59 for June through August 2012 (both significant). The low correlation in winter results from the presence of a prominent $\mathrm{CH}_{4}$ diurnal cycle but lack of a $\mathrm{SF}_{6}$ diurnal cycle. In summer, neither gas has a significant diurnal cycle and a larger correlation is derived.

The role of transport in producing enhancements in mole fractions will now be discussed for each season (excluding spring when only one month of data was available). Methane measurements were first averaged into six hourly values in order to smooth the data and minimize the influence of short duration pollution on this analysis. Average air histories corresponding to the times that measurements are $1 \sigma$ above the mean of the period and for times that they are $1 \sigma$ below the mean were derived. The difference between the two was computed to show the changes in air histories that are likely to be responsible for the observed signals (Figs. 6-8, unsmoothed data shown). At times when $\mathrm{CH}_{4}$ mole fractions are enhanced during the winter, Darjeeling samples a larger extent of the Himalayan region and there is greater sensitivity to the surface. In summer, the air histories corresponding to enhanced measurements show greater sensitivity to northern India while those corresponding to measurements that are low show greater sensitivity in southern India. The majority of $\mathrm{CH}_{4}$ and $\mathrm{N}_{2} \mathrm{O}$ emissions occur in the highly populated Indo-Gangetic plains of northern India (Fig. 1), (Patra et al., 2011; Huang et al., 2008, and references therein). In autumn, as the meteorology transitions from the summer monsoon flow to the winter Himalayan flow, differences in air histories between enhanced and low mole fractions are attributable to both types of flows. As enhancements between $\mathrm{CH}_{4}$ and $\mathrm{N}_{2} \mathrm{O}$ are typically concurrent, similar results are derived for $\mathrm{N}_{2} \mathrm{O}$.

An analysis of transport in producing $\mathrm{SF}_{6}$ enhancements shows that the two events from August and September occur when air masses sampled at Darjeeling come from eastern India and southeast Asia (shown in supplementary material), suggesting the possibility of new $\mathrm{SF}_{6}$ sources in that region that are not included in the Emissions Database for Global 

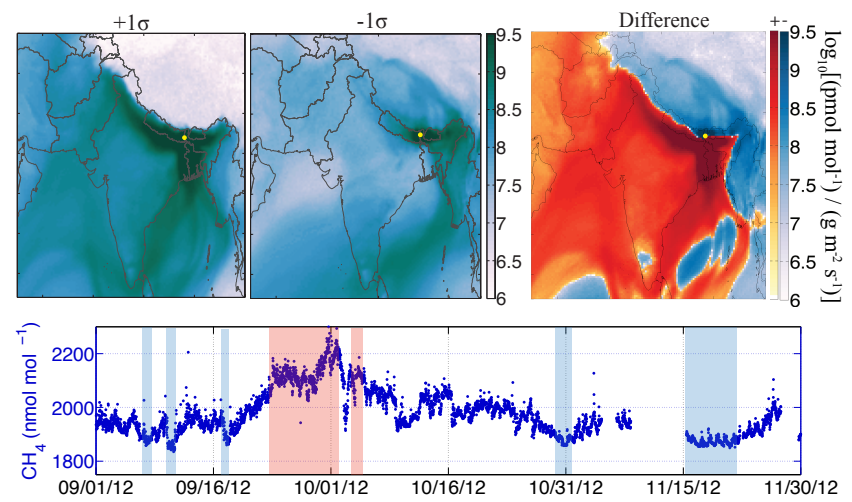

Fig. 8. Same as Fig. 6 but for September 2012 through November 2012.

Atmospheric Research (EDGAR) version 4.2 (JRC/PBL, 2011). Several $\mathrm{SF}_{6}$ enhancements are observed in the winter. The air histories associated with these winter enhancements show small differences in the areas of the Himalayas that are sampled relative to measurements that are not enhanced but do not show a consistent pattern. As the number of $\mathrm{SF}_{6}$ pollution events measured during the year are small relative to the number of pollution events in $\mathrm{CH}_{4}$ and $\mathrm{N}_{2} \mathrm{O}$, these results could be biased towards the few $\mathrm{SF}_{6}$ pollution events.

\subsubsection{Diurnal cycle}

The diurnal cycle is a prominent feature of the measured signal during the winter. The median $\mathrm{CH}_{4}$ diurnal cycles $\left(\mathrm{N}_{2} \mathrm{O}\right.$ and $\mathrm{SF}_{6}$ in the supplementary material) of the different seasons are compared with model-generated diurnal cycles for the same periods (Fig. 9). Simulated $\mathrm{CH}_{4}$ mole fractions were generated using constant monthly emissions fields (Patra et al., 2011, scenario $\mathrm{CH}_{4}$ CCTL_E4 and references therein). Mole fractions were first detrended by subtracting the median value of each running $24 \mathrm{~h}$ period from either the measured or the simulated time series. The median was chosen to minimize the effect of outliers. Variability in both the observed and simulated diurnal cycles are shown as the 16th and 84th percentile values of the month. The size and variability of the simulated diurnal cycles are dependent on the magnitude of emissions and particle release height in the model.

A diurnal cycle in $\mathrm{CH}_{4}$ and $\mathrm{N}_{2} \mathrm{O}$ mole fractions is observed during the winter but is not significant during the summer. During the winter, mole fractions maximize in the afternoon and minimize at night, which is consistent with diurnal profiles of wind direction (upslope from plains during the day) and wind speed (reaches a maximum at $\sim 15: 00$ ) in the mountain system. The model-reproduced $\mathrm{CH}_{4}$ diurnal cycle matches the wintertime phase, with a maximum in both the observed and modeled mole fractions between 15:00-17:00. The agreement of the phase of the diurnal cycle between
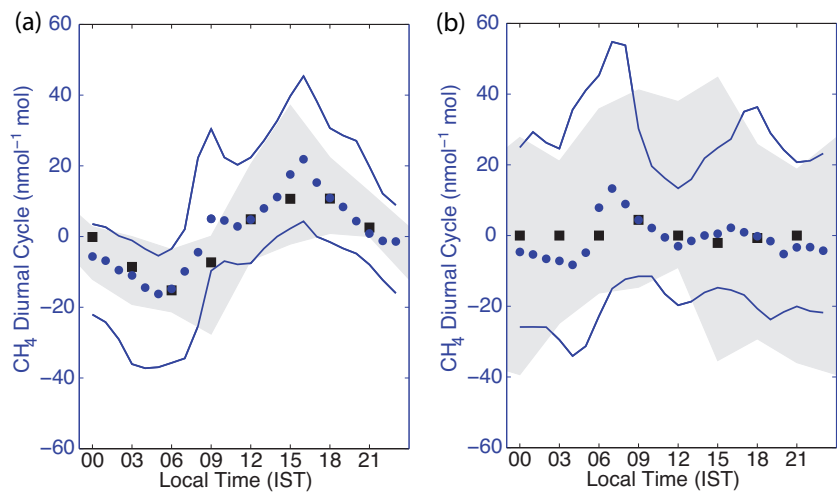

Fig. 9. Median observed $\mathrm{CH}_{4}$ diurnal cycles (blue circles) and NAME-generated diurnal cycles (black squares) from (a) December 2011-February 2012 (winter) and (b) June-August 2012 (summer). Solid blue lines and grey shading indicate the 16th and 84th percentile of the observed and modeled values, respectively, from the period.

model and measurements suggests that the underlying mechanism stems from a large-scale flow. Progressive removal of emissions from a growing radius around the site show that the diurnal cycle is preserved in the simulation even when emissions are removed up to $100 \mathrm{~km}$ away and confirms that the flow being modeled is a large-scale plains-to-mountain flow.

Two peaks are observed throughout the year in the diurnal cycles. One peak occurs between 7:00-9:00 and the second peak occurs between 15:00-17:00. This timing of the morning peak also shifts throughout the year, which is consistent with changes in sunrise time throughout the year. The prominence of the morning peak changes from winter to summer. While the magnitude of the median morning peak signal remains similar, variability in the diurnal cycle grows from winter to summer. This peak may be a result of the ventilation of pollutants from a stable nighttime inversion layer up to the site. The morning peak is a feature that is not captured in this setup of NAME, suggesting that boundary layer processes occurring locally in relation to the Darjeeling slope are not captured at this resolution. The height of release of the model particles may also contribute to this mismatch, as the peak may be a near-surface phenomena. This type of double peak is often seen in "urban pollutants" such as carbon monoxide, where morning and evening rush hours lead to elevated mole fractions (Panday and Prinn, 2009). However, vehicular emissions are not large sources of $\mathrm{CH}_{4}$, and it is thought that this feature is caused mainly by radiative effects rather than by a variable emissions signal.

Nitrous oxide and $\mathrm{SF}_{6}$ diurnal cycles are shown in the supplementary material. Small differences are seen between $\mathrm{CH}_{4}$ and $\mathrm{N}_{2} \mathrm{O}$ diurnal cycles' monthly variability, but the general features are consistent, further supporting the argument for the importance of radiative effects. $\mathrm{An} \mathrm{SF}_{6}$ diurnal 
cycle is not observed in any season, suggesting that sources near the Himalayas are too weak to create a diurnal signal that can be seen within the measurement repeatability.

\section{Summary and conclusions}

The first high-frequency measurements of $\mathrm{CH}_{4}, \mathrm{~N}_{2} \mathrm{O}$ and $\mathrm{SF}_{6}$ from India have been presented in this paper for the period from December 2011 through February 2013; this represents a significant contribution to data for the region. Data from this study can be acquired for research purposes by contacting the lead author of this study.

Several key signals are present in the data. While $\mathrm{SF}_{6}$ mole fractions generally exhibit a slowly varying background signal, suggesting weak sources in the area, $\mathrm{CH}_{4}$ and $\mathrm{N}_{2} \mathrm{O}$ are often polluted and have enhanced mole fractions over the assumed background level. Due to the largely polluted air masses sampled for $\mathrm{CH}_{4}$ and $\mathrm{N}_{2} \mathrm{O}$ throughout the year and the high-frequency sampling of the instrumentation, these data can be used to constrain national-scale emissions from south Asia.

The ability of the transport model to simulate transport at the site shows that the measurements at Darjeeling are representative of the large-scale transport of pollutants. While the January and July monthly mean mole fractions of $\mathrm{CH}_{4}$ are similar, the air histories of measurements during the two seasons are considerably different. In winter, air histories reflect a sensitivity to emissions from the Himalayan region, and a significant diurnal cycle in $\mathrm{CH}_{4}$ and $\mathrm{N}_{2} \mathrm{O}$ mole fractions is both observed and simulated. In contrast with that of winter, the summer monsoon flow is predominantly southwesterly, resulting not only in high surface sensitivity in India and Bangladesh, but also in the transport of southern hemispheric background air.

Many of the enhancements seen in the three gases have been diagnosed as the large-scale transport of pollutants from source regions to Darjeeling. During the summer, many pollution events for the three gases can be explained by transport from the Indo-Gangetic plains of northern India and some $\mathrm{SF}_{6}$ events are shown to result from transport from southeast Asia. Methane and $\mathrm{N}_{2} \mathrm{O}$ enhancements observed during the winter occur when surface sensitivity is higher over a larger area of the Himalayas. Sulfur hexafluoride wintertime pollution events are measured but their air histories show a less consistent pattern than those of $\mathrm{CH}_{4}$ and $\mathrm{N}_{2} \mathrm{O}$, likely due to the few $\mathrm{SF}_{6}$ sources within the Himalayas.

\section{Supplementary material related to this article is available online at http://www.atmos-chem-phys.net/13/ 10633/2013/acp-13-10633-2013-supplement.zip.}

Acknowledgements. We are grateful to Yashodhara Yadav (Bose Institute) for her work in Darjeeling and for her dedicated and meticulous work in operating the instrument. We additionally thank Sibaji Raha, Sanjay Ghosh, Soumendra Singh and D. K. Roy (Bose Institute) for their tremendous efforts in maintaining site infrastructure and coordinating logistics for this project. We also wish to thank Adam Cox, Tim Arnold and Stephanie Mumma (Scripps Institution of Oceanography, SIO) for all the help they have provided with standards and to Martin Vollmer (Empa) for the support in the field. This work was funded by the MIT Center for Global Change Science Director's Fund, the MIT Joint Program on the Science and Policy of Global Change, the Martin Family Society of Fellows for Sustainability, the MIT Energy Initiative, MIT International Science and Technology Initiatives and funding from NASA grant NNX11AF17G to MIT supporting the Advanced Global Atmospheric Gases Experiment (AGAGE). Funding for the Mace Head, Ireland (MHD) and Ragged Point, Barbados (RPB) stations are from the NASA grant to MIT, UK Department of Energy and Climate Change (MHD) and NOAA contract RA133R09CN0062 (RPB). Funding for Cape Matatula, American Samoa (SMO) is from NASA grant NNX07AE87G to SIO and the NASA grant to MIT.

Edited by: J. B. Burkholder

\section{References}

Bergamaschi, P., Frankenberg, C., Meirink, J. F., Krol, M., Villani, M. G., Houweling, S., Dentener, F., Dlugokencky, E. J., Miller, J. B., Gatti, L. V., Engel, A., and Levin, I.: Inverse modeling of global and regional $\mathrm{CH}_{4}$ emissions using SCIAMACHY satellite retrievals, J. Geophys. Res., 114, D22301, doi:10.1029/2009JD012287, 2009.

Bhattacharya, S. K., Borole, D. V., Francey, R. J., Allison, C. E., Steele, L. P., Krummel, P., Langenfelds, R., Masarie, K. A., Tiwari, Y. K., and Patra, P. K.: Trace gases and $\mathrm{CO}_{2}$ isotope records from Cabo de Rama, India, Current Science, 97, 1336-1344, 2009.

Bousquet, P., Ringeval, B., Pison, I., Dlugokencky, E. J., Brunke, E.G., Carouge, C., Chevallier, F., Fortems-Cheiney, A., Frankenberg, C., Hauglustaine, D. A., Krummel, P. B., Langenfelds, R. L., Ramonet, M., Schmidt, M., Steele, L. P., Szopa, S., Yver, C., Viovy, N., and Ciais, P.: Source attribution of the changes in atmospheric methane for 2006-2008, Atmos. Chem. Phys., 11, 3689-3700, doi:10.5194/acp-11-3689-2011, 2011.

Brunner, D., Henne, S., Keller, C. A., Reimann, S., Vollmer, M. K., O'Doherty, S., and Maione, M.: An extended Kalman-filter for regional scale inverse emission estimation, Atmos. Chem. Phys., 12, 3455-3478, doi:10.5194/acp-12-3455-2012, 2012.

Chatterjee, A., Adak, A., Singh, A. K., Srivastava, M. K., Ghosh, S. K., Tiwari, S., Devara, P. C. S., and Raha, S.: Aerosol Chemistry over a High Altitude Station at Northeastern Himalayas, India., PloS one, 5, e11122, doi:10.1371/journal.pone.0011122, 2010.

Chen, Y.-H. and Prinn, R. G.: Estimation of atmospheric methane emissions between 1996 and 2001 using a three-dimensional global chemical transport model, J. Geophys. Res., 111, D10307, doi:10.1029/2005JD006058, 2006. 
Cunnold, D. M., Steele, L. P., Fraser, P. J., Simmonds, P. G., Prinn, R. G., Weiss, R. F., Porter, L. W., O'Doherty, S. J., Langenfelds, R. L., Krummel, P. B., Wang, H. J., Emmons, L. K., Tie, X. X., and Dlugokencky, E. J.: In situ measurements of atmospheric methane at GAGE/AGAGE sites during 1985-2000 and resulting source inferences, J. Geophys. Res., 107, 4225, doi:10.1029/2001JD001226, 2002.

Denman, K., Brasseur, G., Chidthaisong, A., Ciais, P., Cox, P., Dickinson, R., Hauglustaine, D., Heinze, C., Holland, E., Jacob, D., Lohmann, U., Ramachandran, S., da Silva Dias, P., Wofsy, S., and Zhang, X.: Couplings Between Changes in the Climate System and Biogeochemistry, in Climate Change 2007: The Physical Science Basis. Contribution of Working Group I to the Fourth Assessment Report of the Intergovernmental Panel on Climate Change, edited by: Solomon, S., Qin, D., Manning, M., Chen, Z., Marquis, M., Averyt, K. B., Tignor, M., and Miller, H. L., Cambridge University Press, Cambridge, United Kingdom and New York, NY, USA, 2007.

Dlugokencky, E. J., Myers, R. C., Lang, P. M., Masarie, K. A., Crotwell, A. M., Thoning, K. W., Hall, B. D., Elkins, J. W., and Steele, L. P.: Conversion of NOAA atmospheric dry air $\mathrm{CH}_{4}$ mole fractions to a gravimetrically prepared standard scale, J. Geophys. Res., 110, D18306, doi:10.1029/2005JD006035, 2005.

Dlugokencky, E. J., Bruhwiler, L., White, J. W. C., Emmons, L. K., Novelli, P. C., Montzka, S. A., Masarie, K. A., Lang, P. M., Crotwell, A. M., Miller, J. B., and Gatti, L. V.: Observational constraints on recent increases in the atmospheric $\mathrm{CH}_{4}$ burden, Geophys. Res. Lett., 36, L18803, doi:10.1029/2009GL039780, 2009.

Forster, P., Ramaswamy, V., Artaxo, P., Berntsen, T., Betts, R., Fahey, D., Haywood, J., Lean, J., Lowe, D., Myhre, G., Nganga, J., Prinn, R., Raga, G., Schulz, M., and Dorland, R. V.: Changes in atmospheric constituents and in radiative forcing, in: Climate Change 2007: The Physical Science Basis. Contribution of Working Group I to the Fourth Assessment Report of the Intergovernmental Panel on Climate Change, edited by: Solomon, S., Qin, D., Manning, M., Chen, Z., Marquis, M., Averyt, K. B., Tignor, M., and Miller, H. L., Cambridge University Press, Cambridge, United Kingdom and New York, NY, USA, 2007.

Gloor, M., Dlugokencky, E., Brenninkmeijer, C., Horowitz, L., Hurst, D. F., Dutton, G., Crevoisier, C., Machida, T., and Tans, P.: Three-dimensional $\mathrm{SF}_{6}$ data and tropospheric transport simulations: Signals, modeling accuracy, and implications for inverse modeling, J. Geophys. Res., 112, doi:10.1029/2006JD007973, 2007

Hall, B. D., Dutton, G. S., and Elkins, J. W.: The NOAA nitrous oxide standard scale for atmospheric observations, J. Geophys. Res., 112, D09305, doi:10.1029/2006JD007954, 2007.

Hall, B. D., Dutton, G. S., Mondeel, D. J., Nance, J. D., Rigby, M., Butler, J. H., Moore, F. L., Hurst, D. F., and Elkins, J. W.: Improving measurements of SF6 for the study of atmospheric transport and emissions, Atmos. Meas. Tech., 4, 2441-2451, doi:10.5194/amt-4-2441-2011, 2011.

Hofmann, D. J., Butler, J. H., Dlugokencky, E. J., Elkins, J. W., Masarie, K., Montzka, S. A., and Tans, P.: The role of carbon dioxide in climate forcing from 1979 to 2004: introduction of the Annual Greenhouse Gas Index, Tellus B, 58, 614-619, doi:10.1111/j.1600-0889.2006.00201.x, 2006.
Hoskins, B. J. and Rodwell, M. J.: A Model of the Asian Summer Monsoon. Part I: The Global Scale, Journal of the Atmospheric Sciences, 52, 1329-1340, doi:10.1175/15200469(1995)052<1329:AMOTAS>2.0.CO;2, 1995.

Huang, J., Golombek, A., Prinn, R., Weiss, R., Fraser, P., Simmonds, P., Dlugokencky, E. J., Hall, B., Elkins, J., Steele, P., Langenfelds, R., Krummel, P., Dutton, G., and Porter, L.: Estimation of regional emissions of nitrous oxide from 1997 to 2005 using multinetwork measurements, a chemical transport model, and an inverse method, J. Geophys. Res., 113, D17313, doi:10.1029/2007JD009381, 2008.

Indian Network for Climate Change Assessment: India: Greenhouse Gas Emissions 2007, Tech. rep., Ministry of Environments and Forests, Government of India, 2007.

Jones, A., Thomson, D. J., Hort, M. C., and Devenish, B.: The UK Met Office's next-generation atmospheric dispersion model, NAME III, in Air Pollution Modeling and Its Application XVII, edited by: Borrego, C. and Norman, A.-L., Springer, New York, USA, 580-589, 2007.

JRC/PBL: Joint Research Centre of the European Commission (JRC) /Netherlands Environmental Assessment Agency (PBL), Emission Database for Global Atmospheric Research (EDGAR), release version 4.2, 2011.

Levin, I., Naegler, T., Heinz, R., Osusko, D., Cuevas, E., Engel, A., Ilmberger, J., Langenfelds, R. L., Neininger, B., Rohden, C. v., Steele, L. P., Weller, R., Worthy, D. E., and Zimov, S. A.: The global SF6 source inferred from long-term high precision atmospheric measurements and its comparison with emission inventories, Atmos. Chem. Phys., 10, 2655-2662, doi:10.5194/acp-102655-2010, 2010.

Manning, A. J., Ryall, D. B., Derwent, R. G., Simmonds, P. G., and O'Doherty, S.: Estimating European emissions of ozonedepleting and greenhouse gases using observations and a modeling back-attribution technique, J. Geophys. Res., 108, 4405, doi:10.1029/2002JD002312, 2003.

Manning, A. J., O’Doherty, S., Jones, A. R., Simmonds, P. G., and Derwent, R. G.: Estimating UK methane and nitrous oxide emissions from 1990 to 2007 using an inversion modeling approach, J. Geophys. Res., 116, D02305, doi:10.1029/2010JD014763, 2011.

Miller, B. R., Weiss, R. F., Salameh, P. K., Tanhua, T., Greally, B. R., Mühle, J., and Simmonds, P. G.: Medusa: a sample preconcentration and GC/MS detector system for in situ measurements of atmospheric trace halocarbons, hydrocarbons, and sulfur compounds, Anal. Chem., 80, 1536-1545, doi:10.1021/ac702084k, 2008.

Montzka, S. A., Dlugokencky, E. J., and Butler, J. H.: Non$\mathrm{CO}_{2}$ greenhouse gases and climate change, Nature, 476, 43-50, doi:10.1038/nature10322, 2011.

Morrison, N. L. and Webster, H. N.: An Assessment of Turbulence Profiles in Rural and Urban Environments Using Local Measurements and Numerical Weather Prediction Results, Bound.Lay. Meteorol., 115, 223-239, doi:10.1007/s10546-004-4422-8, 2005.

Niemeyer, L. and Chu, F.: $\mathrm{SF}_{6}$ and the atmosphere, IEEE Transactions on Electrical Insulation, 27, 184-187, doi:10.1109/14.123455, 1992.

O’Doherty, S., Cunnold, D. M., Manning, A., Miller, B. R., Wang, R. H. J., Krummel, P. B., Fraser, P. J., Simmonds, P. G., McCul- 
loch, A., Weiss, R. F., Salameh, P., Porter, L. W., Prinn, R. G., Huang, J., Sturrock, G., Ryall, D., Derwent, R. G., and Montzka, S. A.: Rapid growth of hydrofluorocarbon 134a and hydrochlorofluorocarbons 141b, 142b, and 22 from Advanced Global Atmospheric Gases Experiment (AGAGE) observations at Cape Grim, Tasmania, and Mace Head, Ireland, J. Geophys. Res., 109, D06310, doi:10.1029/2003JD004277, 2004.

Panday, A. K. and Prinn, R. G.: Diurnal cycle of air pollution in the Kathmandu Valley, Nepal: Observations, J. Geophys. Res., 114, D09305, doi:10.1029/2008JD009777, 2009.

Park, S., Croteau, P., Boering, K. A., Etheridge, D. M., Ferretti, D., Fraser, P. J., Kim, K.-R., Krummel, P. B., Langenfelds, R. L., van Ommen, T. D., Steele, L. P., and Trudinger, C. M.: Trends and seasonal cycles in the isotopic composition of nitrous oxide since 1940, Nature Geosci., 5, 261-265, doi:10.1038/ngeo1421, 2012.

Parker, R., Boesch, H., Cogan, A., Fraser, A., Feng, L., Palmer, P. I., Messerschmidt, J., Deutscher, N., Griffith, D. W. T., Notholt, J., Wennberg, P. O., and Wunch, D.: Methane observations from the Greenhouse Gases Observing SATellite: Comparison to groundbased TCCON data and model calculations, Geophys. Res. Lett., 38, L15807, doi:10.1029/2011GL047871, 2011.

Pathak, H., Li, C., and Wassmann, R.: Greenhouse gas emissions from Indian rice fields: calibration and upscaling using the DNDC model, Biogeosciences, 2, 113-123, doi:10.5194/bg-2113-2005, 2005.

Patra, P. K., Houweling, S., Krol, M., Bousquet, P., Belikov, D., Bergmann, D., Bian, H., Cameron-Smith, P., Chipperfield, M. P., Corbin, K., Fortems-Cheiney, A., Fraser, A., Gloor, E., Hess, P., Ito, A., Kawa, S. R., Law, R. M., Loh, Z., Maksyutov, S., Meng, L., Palmer, P. I., Prinn, R. G., Rigby, M., Saito, R., and Wilson, C.: TransCom model simulations of $\mathrm{CH}_{4}$ and related species: linking transport, surface flux and chemical loss with $\mathrm{CH}_{4}$ variability in the troposphere and lower stratosphere, Atmos. Chem. Phys., 11, 12813-12837, doi:10.5194/acp-11-12813-2011, 2011.

Prather, M. J. and Hsu, J.: Coupling of Nitrous Oxide and Methane by Global Atmospheric Chemistry, Science, 330, 952-954, doi:10.1126/science.1196285, 2010.

Prinn, R. G., Weiss, R. F., Fraser, P. J., Simmonds, P. G., Cunnold, D. M., Alyea, F. N., O’Doherty, S., Salameh, P., Miller, B. R., Huang, J., Wang, R. H. J., Hartley, D. E., Harth, C., Steele, L. P., Sturrock, G., Midgley, P. M., and McCulloch, A.: A history of chemically and radiatively important gases in air deduced from ALE/GAGE/AGAGE, J. Geophys. Res., 105, 1775117792, doi:10.1029/2000JD900141, 2000.

Ravishankara, A. R., Solomon, S., Turnipseed, A. A., and Warren, R. F.: Atmospheric lifetimes of long-lived halogenated species, Science, 259, 194-199, doi:10.1126/science.259.5092.194, 1993.

Ravishankara, A. R., Daniel, J. S., and Portmann, R. W.: Nitrous oxide $\left(\mathrm{N}_{2} \mathrm{O}\right)$ : the dominant ozone-depleting substance emitted in the 21st century, Science, 326, 123-125, doi:10.1126/science.1176985, 2009.

Reimann, S., Manning, A. J., Simmonds, P. G., Cunnold, D. M., Wang, R. H. J., Li, J., McCulloch, A., Prinn, R. G., Huang, J., Weiss, R. F., Fraser, P. J., O’Doherty, S., Greally, B. R., Stemmler, K., Hill, M., and Folini, D.: Low European methyl chloroform emissions inferred from long-term atmospheric measurements, Nature, 433, 506-508, doi:10.1038/nature03220, 2005.
Rigby, M., Prinn, R. G., Fraser, P. J., Simmonds, P. G., Langenfelds, R. L., Huang, J., Cunnold, D. M., Steele, L. P., Krummel, P. B., Weiss, R. F., O’Doherty, S., Salameh, P. K., Wang, H. J., Harth, C. M., Mühle, J., and Porter, L. W.: Renewed growth of atmospheric methane, Geophys. Res. Lett., 35, L22805, doi:10.1029/2008GL036037, 2008.

Rigby, M., Mühle, J., Miller, B. R., Prinn, R. G., Krummel, P. B., Steele, L. P., Fraser, P. J., Salameh, P. K., Harth, C. M., Weiss, R. F., Greally, B. R., O’Doherty, S., Simmonds, P. G., Vollmer, M. K., Reimann, S., Kim, J., Kim, K.-R., Wang, H. J., Olivier, J. G. J., Dlugokencky, E. J., Dutton, G. S., Hall, B. D., and Elkins, J. W.: History of atmospheric SF6 from 1973 to 2008, Atmos. Chem. Phys., 10, 10305-10320, doi:10.5194/acp10-10305-2010, 2010.

Rinsland, C. P., Brown, L. R., and Farmer, C. B.: Infrared spectroscopic detection of sulfur hexafluoride (sf6) in the lower stratosphere and upper troposphere, J. Geophys. Res., 95, 5577-5585, doi:10.1029/JD095iD05p05577, 1990.

Ryall, D. B. and Maryon, R. H.: Validation of the UK Met. Office's name model against the ETEX dataset, Atmos. Environ., 32, 4265-4276, doi:10.1016/S1352-2310(98)00177-0, 1998.

Saikawa, E., Prinn, R. G., Dlugokencky, E., Ishijima, K., Dutton, G. S., Hall, B. D., Langenfelds, R., Tohjima, Y., Machida, T., Manizza, M., Rigby, M., O’Doherty, S., Patra, P. K., Harth, C. M., Weiss, R. F., Krummel, P. B., van der Schoot, M., Fraser, P. B., Steele, L. P., Aoki, S., Nakazawa, T., and Elkins, J. W.: Global and regional emissions estimates for $\mathrm{N}_{2} \mathrm{O}$, Atmos. Chem. Phys. Discuss., 13, 19471-19525, doi:10.5194/acpd-13-194712013, 2013.

Schuck, T. J., Brenninkmeijer, C. A. M., Baker, A. K., Slemr, F., von Velthoven, P. F. J., and Zahn, A.: Greenhouse gas relationships in the Indian summer monsoon plume measured by the CARIBIC passenger aircraft, Atmos. Chem. Phys., 10, 3965 3984, doi:10.5194/acp-10-3965-2010, 2010.

Thompson, R. L., Chevallier, F., Crotwell, A. M., Dutton, G., Langenfelds, R. L., Prinn, R. G., Weiss, R. F., Tohjima, Y., Nakazawa, T., Krummel, P. B., Steele, L. P., Fraser, P., Ishijima, K., and Aoki, S.: Nitrous oxide emissions 1999-2009 from a global atmospheric inversion, Atmos. Chem. Phys. Discuss., 13, 15697-15747, doi:10.5194/acpd-13-15697-2013, 2013.

Thoning, K. W., Tans, P. P., and Komhyr, W. D.: Atmospheric carbon dioxide at Mauna Loa Observatory: 2. Analysis of the NOAA GMCC data, 1974-1985, J. Geophys. Res., 94, 85498565, doi:10.1029/JD094iD06p08549, 1989.

Tuzson, B., Henne, S., Brunner, D., Steinbacher, M., Mohn, J., Buchmann, B., and Emmenegger, L.: Continuous isotopic composition measurements of tropospheric $\mathrm{CO}_{2}$ at Jungfraujoch (3580 m a.s.1.), Switzerland: real-time observation of regional pollution events, Atmos. Chem. Phys., 11, 1685-1696, doi:10.5194/acp-11-1685-2011, 2011.

Vollmer, M. K. and Weiss, R. F.: Simultaneous determination of sulfur hexafluoride and three chlorofluorocarbons in water and air, Marine Chem., 78, 137-148, doi:10.1016/S03044203(02)00015-4, 2002.

Xiong, X., Houweling, S., Wei, J., Maddy, E., Sun, F., and Barnet, C.: Methane plume over south Asia during the monsoon season: satellite observation and model simulation, Atmos. Chem. Phys., 9, 783-794, doi:10.5194/acp-9-783-2009, 2009. 